\title{
Vegetation change in peatland buffers as an indicator of active areas of run-on from forestry
}

\author{
Päivi Saari ${ }^{1}$, Veli Saari², Hannu Luotonen ${ }^{3}$ \& Jukka Alm ${ }^{1}$ \\ 1) Finnish Forest Research Institute, Joensuu Research Unit, P.O. Box 68, Fl-80101 Joensuu, \\ Finland (e-mails: paivi.saari@metla.fi, jukka.alm@metla.fi) \\ 2) Department of Biological and Environmental Science, P.O. Box 35, Fl-40014 University of \\ Jyväskylä, Finland (e-mail: vsaari@elisanet.fi) \\ 3) North Karelia Centre for Economic Development, Transport and the Environment, P.O. Box 69, \\ Fl-80101 Joensuu, Finland (e-mail: hannu.luotonen@ely-keskus.fi)
}

Received 17 June 2009, revised version received 1 Dec. 2009, accepted 28 Dec. 2009

Saari, P., Saari, V., Luotonen, H. \& Alm, J. 2010: Vegetation change in peatland buffers as an indicator of active areas of run-on from forestry. - Ann. Bot. Fennici 47: 425-438.

Our aim in this study was to evaluate whether coverage change in the vegetation of a forestry buffer wetland can be used to reveal a possible increase in nutrients. To achieve this, we followed changes in vegetation on two peatland buffers, and biomass with nitrogen content in one of them. Nutrient concentrations were periodically lower in the water inflow than in the outflow. Flooding caused a species change in favor of flood-tolerant grasses and Sphagna, but this species composition did not indicate a higher trophic level. Nitrogen content in the reference site's original surface peat layer, which was rich in woody remains, was higher than that of the newly formed, more acidic Sphagnum peat of the spruce swamp buffer. Changes in biomass did not indicate an increased nutrient-binding capacity of the spruce swamp buffer vegetation. On the other hand, the changes in species cover outlined the area of effective water flow paths within the buffer and suggested that severe eutrophication of peatland forestry buffers does not seem likely.

Key words: above-ground biomass, buffer zone, detrended correspondence analysis, peatland forestry, nitrogen content, tree stand, vegetation change

\section{Introduction}

The area of forestry in Finland covers about 26 million ha (Peltola 2008), of which 4.8 million ha are on drained peatlands. Forestry operations are shown to increase concentration of nutrients in soil solution leaching from the catchment (e.g. Sollins \& McCorison 1981, Nieminen 2004, Piirainen et al. 2004, Piirainen et al. 2007, Morris 2009). In the year 2007, 688000 ha of the total forest area was under harvesting operations, on 130000 ha soil preparation was being carried out, on 67000 ha ditch cleaning was in progress and 35000 ha was under fertilization (Peltola 2008). Clear-cuttings do not always significantly increase the leaching of phosphorus $(\mathrm{P})$, even though extra nitrogen $(\mathrm{N})$ is liberated (Nieminen 2004, Piirainen et al. 2004, Mannerkoski et al. 2005). However, soil preparation and ditch cleaning in drainage operations can 
cause a short-term (from 1 to 2 years) release of both P (Joensuu et al. 2001b, Piirainen et al. 2007) and N (Piirainen et al. 2007). Fertilization in peatlands also adds to the liberation of nutrients (e.g. Saura et al. 1995, Liljaniemi et al. 2003). However, several forestry operations may take place in different parts of the catchment simultaneously, or the operations may be timed to occur over a time span of several years.

Peatlands drained for forestry, having a short water retention time due to the effective ditch network, constitute an important threat to water quality. Forestry operations in peatlands and the associated ditch cleaning will increase in the near future as first generation forests mature. With the aim of diminishing the pollution risk to watercourses due to peatland forestry, buffers have been established for capturing solids and nutrients from the forestry operations already in the catchments. Waters from such catchments may be distributed to a peatland buffer area through a sedimentation pond, often delimited by a dam. The solids are assumed to sediment in the pond and the dam to raise the waters into an overland flow. The terminology concerning wetlands under artificial flooding is diverse. In this article we call peatland areas affected by water flooding through the pond (peatland) buffers.

Nutrient binding is thought to occur physically, chemically and biologically. Silvan et al. (2004) estimated that most of the $\mathrm{N}$ load and some of the $\mathrm{P}$ was captured by plant growth and tissues. Much of the trapped P is chemically bound in soil (e.g. Väänänen et al. 2006) or immobilized in microbial biomass (Silvan et al. 2003). Several previous studies assessed the role of vegetation biomass in nutrient binding. In a fertilization experiment carried out on a peatland forestry buffer and a peat mining overland flow wetland, the total plant biomass increased by about $20 \%$ during one year after fertilization (Silvan et al. 2004), or as compared with that in the control area (Huttunen et al. 1996). Plant biomass doubled during ten years in a wetland constructed for purifying the run-off from peat mining (Liikanen et al. 2006). A great increase in the biomass of Eriophorum vaginatum and various Sphagnum species was recorded by Silvan et al. (2004), but they did not note enhanced $\mathrm{N}$ concentration in the tissues of buffer vegetation.
By contrast, Huttunen et al. (1996) measured a $40 \%$ increase in total $\mathrm{N}$ in the plant biomass, but a simultaneous decrease in $\mathrm{P}$ content.

Changes in vegetation structure have been reported earlier. According to Liikanen et al. (2006), Sphagnum angustifolium and S. papillosum had decreased in abundance in a buffer zone capturing peat mining waters ten years after buffer construction, while Carex lasiocarpa and Potentilla palustris had increased. It would seem from this study that vascular plants store the nutrients in the long run, since E. vaginatum, C. lasiocarpa and P. palustris have large belowground biomass, extending deep into the peat, where the possibly slow turnover of dead roots may pass the active nutrient cycle.

Controlling the true functioning of the peatland buffer is difficult, and no indicators for good nutrient retention are available. Hitherto, a large buffer area has been considered the most important factor for nutrient binding (e.g. Väänänen $e t$ al. 2008). Here we assume that the distribution of vegetation and the species composition displays the effective area of the water paths flowing in the buffer. We compared vegetation cover changes in two peatland forestry buffer wetlands with those in reference areas outside the influence of flooding. We postulated that changed vegetation could be an indicator of the extent of the buffer area receiving nutrient-rich waters, in a way that is similar to the way in which ground vegetation indicates fertility between forest or mire site type. Finding such indications, familiar in forestry practice, would help planners to evaluate whether the buffers were in the first place constructed in areas critical for water protection. We also aimed to investigate whether other, more indirect factors than nutrients, such as changed $\mathrm{pH}$ or increased light in gaps created by fallen trees, affect vegetation change.

\section{Material and methods}

\section{Study sites}

A spruce swamp $\left(63^{\circ} 38^{\prime} \mathrm{N}, 2^{\circ} 25^{\prime} \mathrm{E}, 192 \mathrm{~m}\right.$ a.s.l. $)$ peatland buffer and a brook margin meadow peatland buffer $\left(63^{\circ} 37^{\prime} \mathrm{N}, 29^{\circ} 30^{\prime} \mathrm{E}, 186 \mathrm{~m}\right.$ a.s.1.) were established in 1997 in the catchment of 
a) Catchment
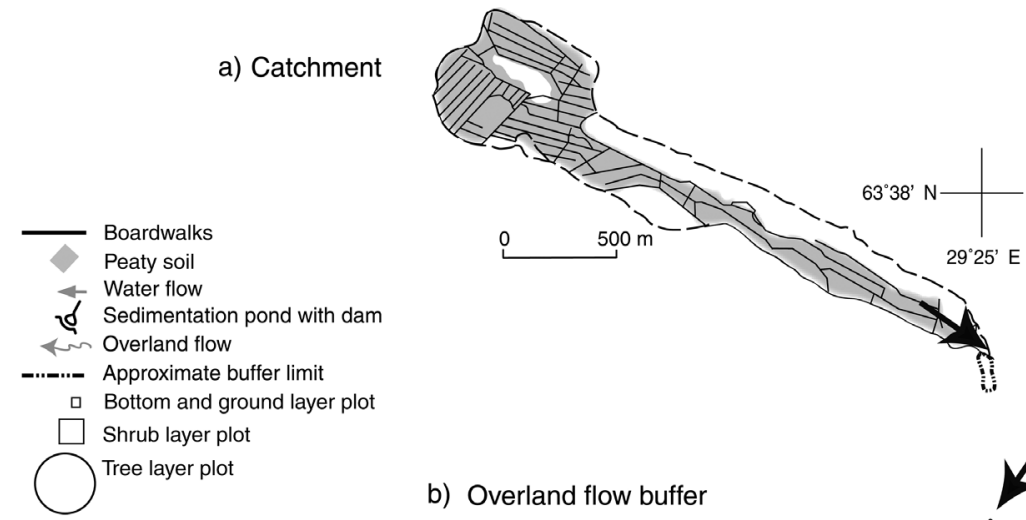

Fig. 1. Map of the spruce swamp study area.
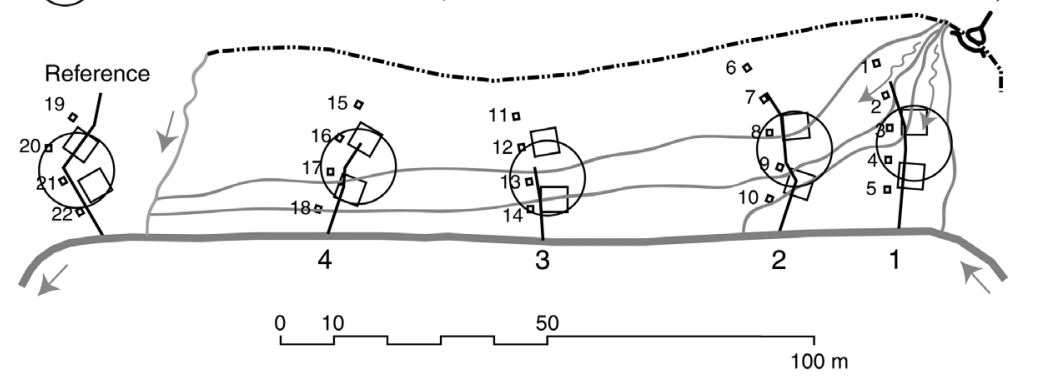

Kuohattijärvi, a lake in Nurmes, eastern Finland (Fig. 1). In the Nurmes area, the annual mean temperature and precipitation calculated for the sampling years are $+3.0^{\circ} \mathrm{C}$ and $533 \mathrm{~mm}$, respectively (Finnish Meteorological Institute). The study sites consisted of a sedimentation pond and a dam to guide the incoming waters to a surface flow through the buffer. The spruce swamp buffer represented $0.5 \%$ of the 72 ha forest catchment which was under forestry operations, including ditch cleaning, PK fertilization, thinning, and harvesting. The brook margin meadow represented $0.16 \%$ of a 29 ha catchment under thinning, ditch cleaning and PK fertilization.

In the spruce swamp, five transects were positioned at increasing distances from the inflow. Of the transects, number 5 was established outside the buffer as a reference (Fig. 1). The peat depth was $50-60 \mathrm{~cm}$ in the buffer and about $30 \mathrm{~cm}$ in the reference. In the brook margin meadow, three transects were located below the sedimentation pond and the reference at a paludified upstream bank of the brook (Fig. 2). The peat depths in the brook margin meadow buffer and in the reference were 190 and $150 \mathrm{~cm}$, respectively. Permanent vegetation plots (moss and ground layer plots, shrub plots and tree layer plots) were located along the transects at different distances from the sedimentation pond (Figs. 1 and 2).

\section{Vegetation characteristics}

The coverage of vascular plants and moss species projection was estimated in July 2005, 2006 and 2007 separately for moss and ground layers at both study sites using the following scale: + (species present), $0.5 \%, 1 \%, 2 \%, 3 \%, 5 \%, 7 \%$, $10 \%$ and above at $5 \%$ increaments to $100 \%$. The proportion of litter and dead plants was also estimated on 22 and $161-\mathrm{m}^{2}$ plots along the transects in the spruce swamp and in the brook margin meadow, respectively (Figs. 1 and 2).

The coverage of the shrub layer (arborescent plants with a height of at least $0.5 \mathrm{~m}$ ) was also estimated as a percentage $(0.5 \%, 1 \%, 2 \%, 3 \%$, $5 \%, 7 \%, 10 \%$ and above at $5 \%$ increaments to $100 \%)$. The surveys were conducted in July 2005, 2006 and 2007 on ten and five $25-\mathrm{m}^{2}$ plots in the spruce swamp and in the brook margin meadow, respectively. A trunk diameter at $1.3 \mathrm{~m}$ for each tree species was measured in 2007, and the tree stand density and canopy coverage were estimated on five 0.01-ha circular plots. The 


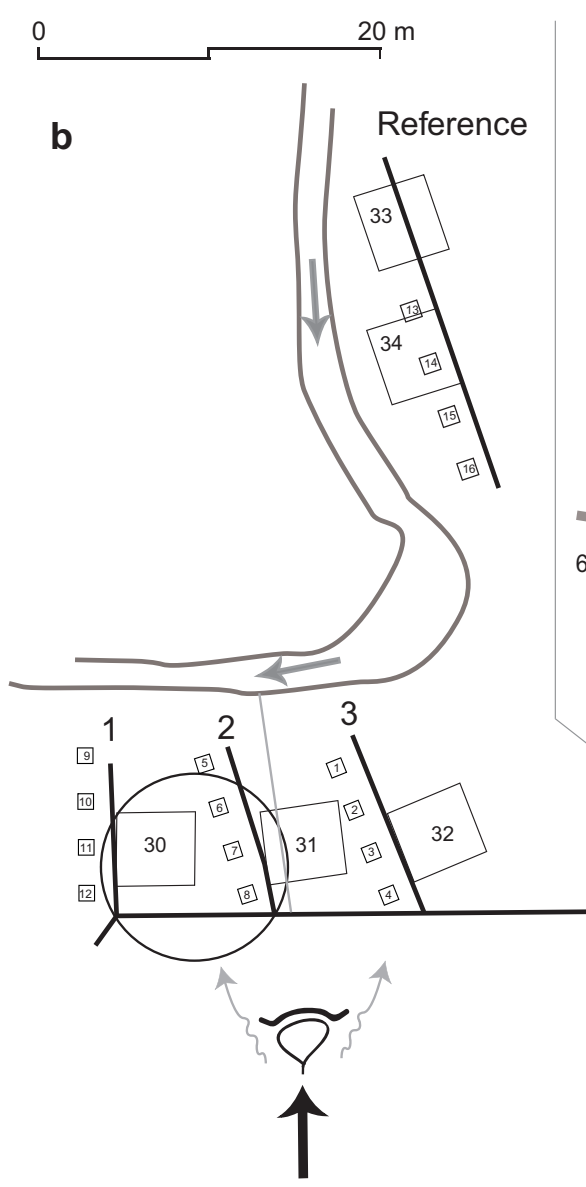

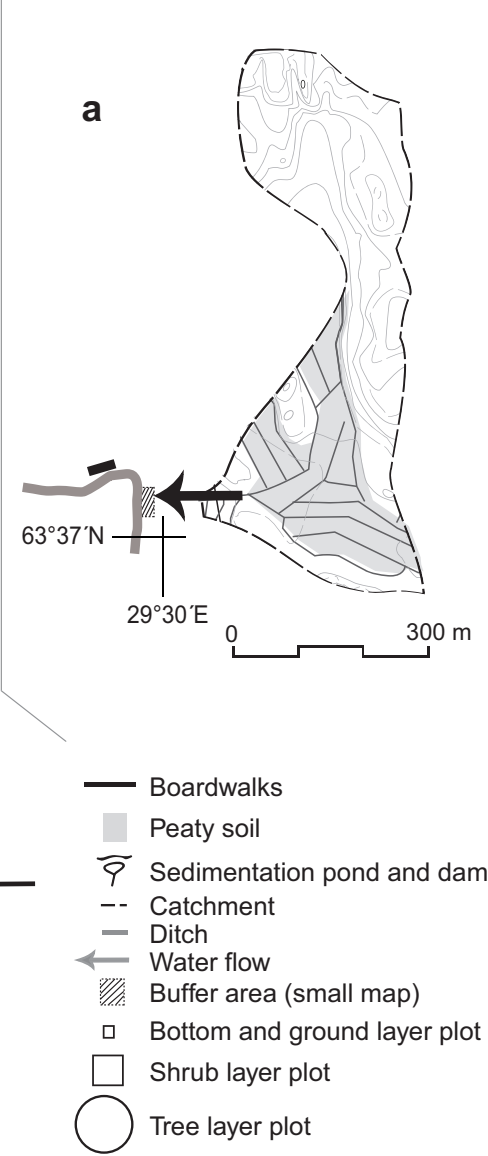

Fig. 2. Map of the brookmargin meadow study area. - a: Catchment b: Overland flow buffer. partially overlapping canopy areas were summed per each plot and presented as a percentage of the maximum value. The lower percentages are assumed to indicate less light extinction in the canopy. The circular plots were examined first in October 2005 and again in May 2007. Only one circular plot was examined in the brook margin meadow. Due to the small size of the plots, combined with the timing and short duration of our monitoring period, we were unable to monitor the mortality rates. We, therefore, counted and measured all live and dead trees in the spruce swamp where the amount of dead or dying trees was high. The live or dead status for all trees or old stumps from an earlier harvest was recorded along the study transects with the aim of estimating the effects of buffer construction on the tree stand at different distances from the sedimentation pond towards the reference.

\section{Water levels and water quality}

Water table levels, indicating flooding and the depth of the aerobic peat layer, were measured weekly from 4-5 water wells (50-cm deep, $32 \mathrm{~mm}$ in diameter) along each transect. Water samples for $\mathrm{pH}$ measurements (PHM 92 Radiometer) were taken at least once a month from June 2005 to May 2006 during the frost-free period.

Water samples for analysis of $\mathrm{N}_{\text {TOT }}, \mathrm{NH}_{4}^{+}$, and $\mathrm{NO}_{2}^{-}+\mathrm{NO}_{3}^{-}$were taken from the sedimentation pond (inflow) and the outflow beyond transect 4 during the years 2000-2005, 2-10 times per year, and analyzed spectrophotometrically. Total $\mathrm{N}, \mathrm{NO}_{2}+\mathrm{NO}_{3}$ and $\mathrm{NH}_{4}{ }^{+}$were analyzed using the standards SFS-EN ISO 11905-1, SFS-EN ISO 13395 and SFS 3032, respectively. Total P and $\mathrm{PO}_{4}^{3-}$ were analyzed using spectrophotometric methods (standard SFS-EN ISO 6878). 


\section{Ground vegetation and tree biomass and their total nitrogen content in the spruce swamp}

Above-ground parts of vascular plants and moss capitula were collected from one $0.25-1 \mathrm{~m}^{2}$ vegetation plot per transect and the reference (plots 4, 9, 14, 18 and 21). Peat samples were cut at a depth of $10 \mathrm{~cm}$ below the moss capitula. Vegetation, moss and peat samples were dried at $40{ }^{\circ} \mathrm{C}$, homogenized, and measured for moisture using the standard ISO 11465 and total $\mathrm{N}$ content using the standard VYH-76.

We estimated the potential $\mathrm{N}$ and $\mathrm{P}$ liberation from trees killed by increased water table after buffer construction by comparing the amounts of $\mathrm{N}$ and $\mathrm{P}$ bound by dead and live tree biomass for the different species reported by Finér (1989) and Repola et al. (2007).

\section{Analysis of plant communities and environmental variables}

We used the approach familiar from the Finnish forest site type classification for characterizing the vegetation change where peatland fertility and moisture are displayed in ground vegetation and tree stand (Cajander 1913, Laine \& Vasander 2008). The biotope types on the buffer and the reference were classified in the field according to the Finnish ecological mire site type classification system (Eurola et al. 1995).

Changes in vegetation coverage from 2005 to 2007 were illustrated as re-location of plots according to axis score values for the consecutive years computed using detrended correspondence analysis (DCA). The analysis was run using standard options, but with down-weighting of rare species. The matrix consisted of $71 \mathrm{veg}-$ etation plots and 47 species in the spruce swamp and 48 plots and 46 species in the brook margin meadow.

In the spruce swamp and brook margin meadow data, a linear mixed model was used for testing the differences in water table level and $\mathrm{pH}\left(y_{i j k l m}\right)$ between the different parts of the study site (Eq. 1):

$y_{i j k l m}=m+$ fixed effects + random effects $+e_{i j k l m}$. where $m$ is the intercept. Fixed effects include the following parameters: transect ${ }_{i}$ (i.e. the distance from the inflow), ditch (i.e. the distance of the study plot from the margin ditch [Spruce swamp, Fig. 1]), brook $_{j}$ (i.e. the distance of the study plot from the margin brook [Brook margin meadow, Fig. 2]), season $_{k}$ (i.e. the seasonality effect), well ${ }_{i l}$ (i.e. the location of the plot), the random term, and $e_{i j k l m}$ (i.e. the residual term for the $m$ th measurement of the well $\left.i_{i j k l m}\right)$. It was assumed that the distributions of the error vectors $\boldsymbol{e}_{i j k l}=\left(\boldsymbol{e}_{i j k l 1}\right.$, $\left.\boldsymbol{e}_{i j k l 2}, \boldsymbol{e}_{i j k l 3}, \ldots, \boldsymbol{e}_{i j k l m}\right)$ are independent multivariate normal random vectors with homogenous variance and a first order autoregressive covariance structure. The normality of the marginal distribution of the residuals and the homogeneity of the variance of the residuals were checked graphically, and the selection of the covariance structure was based on Akaike's information criteria.

\section{Results}

\section{Vegetation composition}

In DCA analysis of the vegetation composition on the spruce swamp (Fig. 3), Axis 1 (eig. = 0.74) divides the vegetation plots mainly into two different mire types, fern spruce mire and Myrtillus spruce mire, while Axis 2 (eig. = 0.42) separates the areas of overland flooding and nonflooded forest. Correspondingly, at the species level (Fig. 4), the indicators of flooding (e.g. Calamagrostis purpurea and Juncus filiformis; Eurola et al. 1995) were found to the left of the Axis 1 origo, while the forest dwarf shrubs and mosses, such as Vaccinium myrtillys, V. vitisidaea, Pleurozium schreberi and Hylocomium splendens to the right. The separation of the two groups on Axis 1 was based on indicators of the spruce mire site type (Eurola et al. 1995, bufferMyrtillus spruce mire, e.g. Equisetum sylvaticum and Sphagnum centrale). The flood indicators, such as Sphagnum riparium, $S$. girgensohnii and Straminergon stramineum, occupied the lower end of Axis 2 as compared with the original vegetation of forest herbs and mosses, e.g. Oxalis acetocella and Dicranum polysetum.

On the spruce swamp, the original gradient in vegetation from the Myrtillus spruce mire type to 


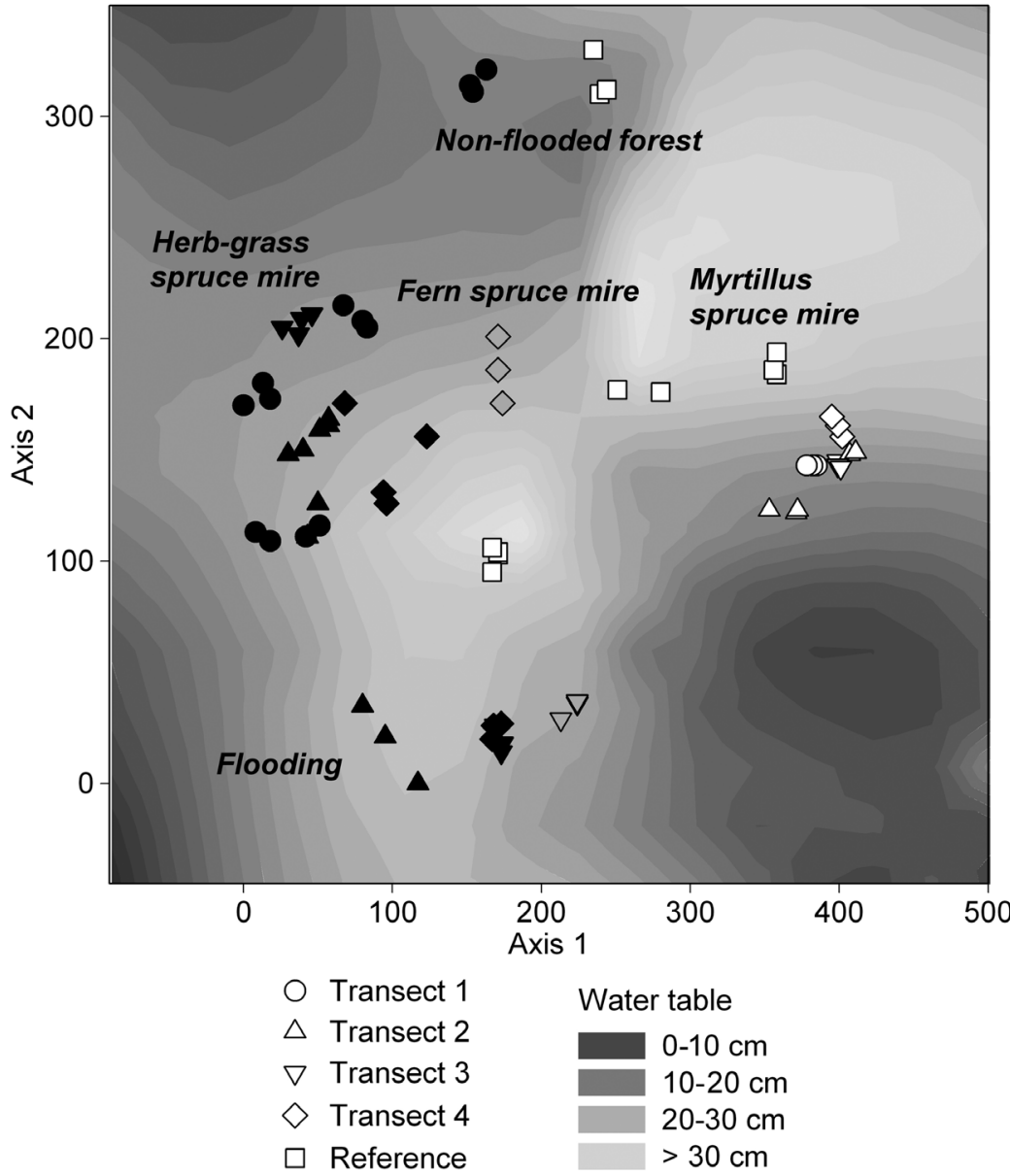

Fig. 3. DCA analysis of the spruce swamp with spatially smoothed average summer 2005 water table level for vegetation plots. Black symbols describe the flooded end, white symbols the non-flooded end of the buffer or reference, and gray symbols the vegetation plots with occasional flooding. the fern or Equisetum sylvaticum spruce mire type was even steeper in the DCA ordination (Axis 1, Figs. 3 and 4) ten years after buffer construction than that resulting from the overland water flows (Axis 2). Although Axis 2 was shorter than Axis 1, this does not mean that the vegetation change due to flooding was insignificant, but rather that the $\alpha$ diversity in the flooded area (average number of species 7.6) was lower than that in the reference and the non-flooded margin (10.1). The coverage of the shrub layer averaged 15\% near the inflow to the buffer (transect 1), decreasing further away to $0.5 \%$ on transect 2 and $4.5 \%$ on transect 3,4 and outside the buffer at the reference site. Salix phylicifolia was found only on transect 1 , where Picea abies, a typical species for the shrub layer elsewhere, was missing.

In the brook margin meadow, DCA segregated the vegetation plots in the buffer and in the reference into two separate groups on Axis 1 (eig. = 0.91; Fig. 5), here named "Herb-grass spruce mire buffer" and "Swamp fen reference", respectively. Probably the development of the buffer meadow and the reference had been different, partly because of their different positions with respect to the brook sediment accumulation. The buffer meadow's development was affected by slower current and sediment accumulation, while the peat layer in the reference was apparently formed by terrestrialisation of the riparian zone. For this reason, the sub-site intended as a reference did not properly correspond to the conditions prior to buffer establishment, and we could not utilize the reference-buffer comparison. The heterogeneity on Axis 2 (eig. $=0.18$ ) was due to differences in species abundance along the reference (Fig. 5), so that plots 13 and 14 had flooding indicators such as Calla palus- 
Fig. 4. DCA analysis for the species on the spruce swamp. The abbreviations of species were constructed by taking three first letters from both words of the species names (see Appendix 1).

Fig. 5. DCA analysis for vegetation plots on the brook margin meadow. The numbers refer to vegetation plots (1-16) and years (2005-2007).
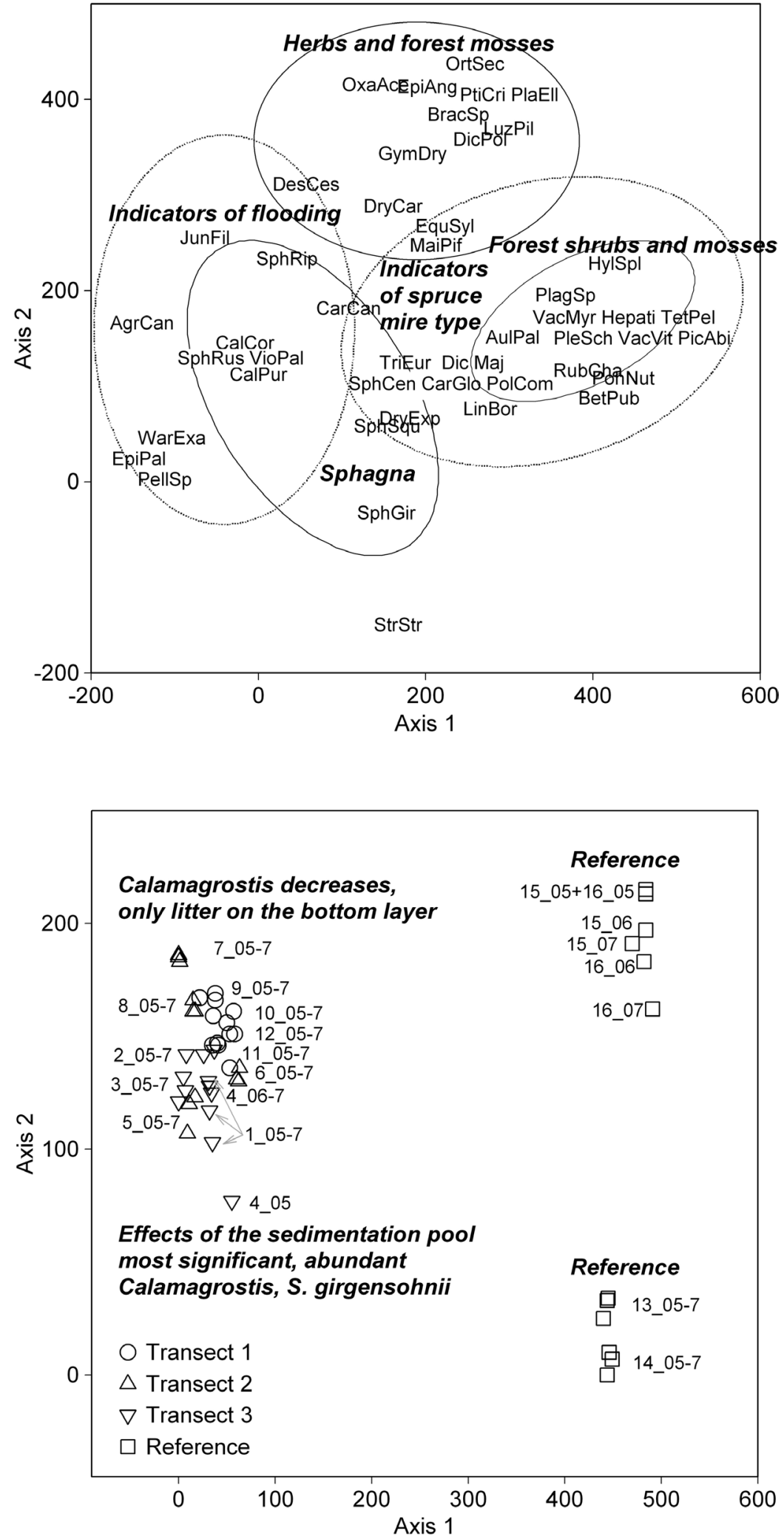


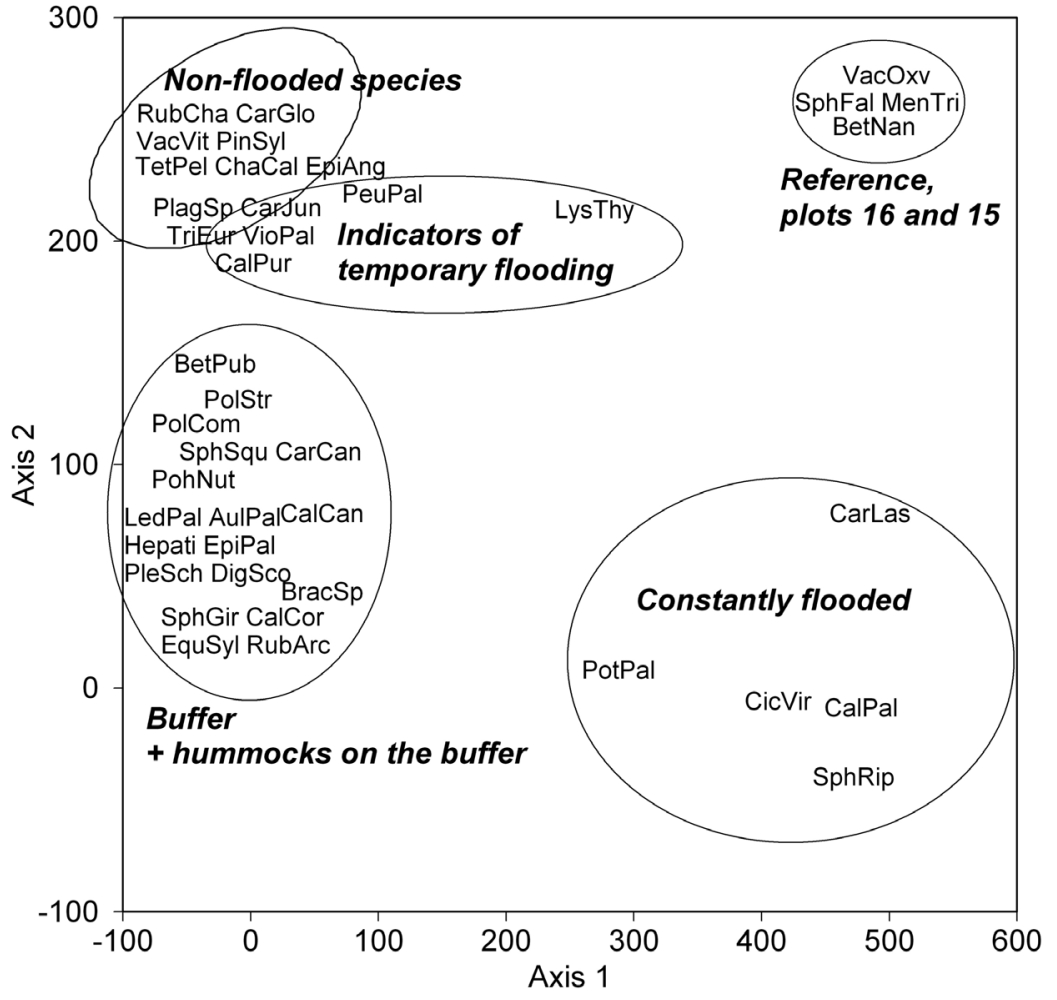

Fig. 6. DCA analysis for species on the brook margin meadow. Abbreviations of species were constructed by taking three first letters from both words of the species names (see Appendix 2). tris, Potentilla palustris, Sphagnum riparium, and plots 15 and 16 also had in abundance indifferent fen species such as Carex lasiocarpa, Vaccinium oxycoccos and Sphagnum fallax. In addition, the heterogeneity on Axis 2 was due to microsite variation (Fig. 6). Bryophytes were found on hummocks and some were found on old stumps. Flat surfaces were either dwarf shrub dominated non-flooded areas or temporarily flooded with Calamagrostis purpurea and Viola palustris. The coverage of the shrub layer was $7 \%-50 \%$ on the buffer and $1 \%-30 \%$ on the reference. Both Betula pubescens and Salix phylicifolia were found on the buffer and on the reference, but one difference between the two was that no Pinus sylvestris or Salix aurita was found on the buffer and no Alnus incana was found on the reference.

\section{Tree stand}

There was no change in the amount of dead trees or tree canopy coverage on the spruce swamp or the brook margin meadow circular plots between years 2005 and 2007 (Table 1). However, more trees were alive in the dry areas of the spruce swamp buffer (transect 4) and in the reference area. No dead trees were found on the brook margin meadow, where the present trees were low-growing (height 4-12 m) and the species were adapted to flooding even before the buffer construction.

Comparison of the proportion of tree deaths between the spruce swamp transects revealed that about $40 \%$ of trees were dead on the wettest transect 1 (Table 2). On transects 2, 3 and 4, the proportions were $35 \%, 19 \%$ and $20 \%$, respectively. On the reference only $4 \%$ of the tree stand was dead. The tree canopy opened after the trees had lost their needles and the trunks had fallen (Table 1). Most of the dead trees, especially on transects 1-3, were colonized by saprotroph fungus Fomitopsis pinicola.

The biomass of live trees was highest on the reference, where the proportion of dead trees was low, and there were no stumps from previous cuttings (Table 2). Within the buffer, the decomposing tree biomass apparently released nutrients such as $\mathrm{N}$ and $\mathrm{P}$ (Table 2). Based on the 
Table 1. The number of live and dead trees with relative canopy cover of live trees on tree-stand circles in the spruce swamp and brook margin meadow between 2005 and 2007 . There was no change in the numbers of live and dead trees and canopy coverage between the years. (n.a. = not applicable).

\begin{tabular}{|c|c|c|c|c|c|c|c|c|}
\hline \multirow[t]{2}{*}{ Study site } & \multirow[t]{2}{*}{ Plot } & \multicolumn{2}{|c|}{ Picea abies } & \multicolumn{2}{|c|}{$\begin{array}{c}\text { Betula } \\
\text { pubescens }\end{array}$} & \multirow{2}{*}{$\begin{array}{c}\text { Betula } \\
\text { pendula } \\
\text { live }\end{array}$} & \multirow{2}{*}{$\begin{array}{c}\text { Alnus } \\
\text { glutinosa } \\
\text { live }\end{array}$} & \multirow[t]{2}{*}{$\begin{array}{l}\text { Relative canopy coverage } \\
(\%)\end{array}$} \\
\hline & & Live & Dead & Live & Dead & & & \\
\hline \multirow[t]{5}{*}{ Spruce swamp } & 1 & 2 & 2 & - & - & - & - & 48 \\
\hline & 2 & - & 3 & 2 & - & - & - & 51 \\
\hline & 3 & 1 & 2 & 1 & - & - & - & 100 \\
\hline & 4 & 4 & 2 & - & - & - & - & 95 \\
\hline & 5 & 5 & - & 1 & - & - & - & 98 \\
\hline Brook margin meadow & 1 & - & - & - & - & 12 & 2 & n.a. \\
\hline
\end{tabular}

Table 2. Number and biomass $(\mathrm{kg})$ of live and dead trees and stumps, and their estimated contents of $\mathrm{N}$ and $P(\mathrm{~kg})$ in the 0.5 ha spruce swamp buffer and on the 0.1 ha reference.

\begin{tabular}{|c|c|c|c|}
\hline \multirow[t]{2}{*}{ Transect } & \multicolumn{3}{|c|}{ Number } \\
\hline & Live trees & Dead trees & Stumps \\
\hline 1 & 78 & 18 & 13 \\
\hline 2 & 71 & 21 & 4 \\
\hline 3 & 86 & 15 & 1 \\
\hline 4 & 97 & 5 & 14 \\
\hline \multirow[t]{3}{*}{ Reference } & 97 & 4 & 0 \\
\hline & \multicolumn{3}{|c|}{ Biomass (kg) } \\
\hline & Live trees & Dead trees & Stumps \\
\hline 1 & 7916 & 5472 & 1133 \\
\hline 2 & 4795 & 6077 & 108 \\
\hline 3 & 9501 & 4245 & 92 \\
\hline 4 & 12017 & 1484 & 713 \\
\hline \multirow[t]{3}{*}{ Reference } & 19276 & 1204 & 0 \\
\hline & \multicolumn{3}{|c|}{$\mathrm{N}(\mathrm{kg})$} \\
\hline & Live trees & Dead trees & Stumps \\
\hline 1 & 20.5 & 15.8 & 1.7 \\
\hline 2 & 13.7 & 20.8 & 0.2 \\
\hline 3 & 30.5 & 11.4 & 0.1 \\
\hline 4 & 33.5 & 4.4 & 1.1 \\
\hline \multirow[t]{3}{*}{ Reference } & 49.8 & 3.3 & 0 \\
\hline & \multicolumn{3}{|c|}{$P(k g)$} \\
\hline & Live trees & Dead trees & Stumps \\
\hline 1 & 1.7 & 1.3 & 0.15 \\
\hline 2 & 1.0 & 1.8 & 0.01 \\
\hline 3 & 2.3 & 0.9 & 0.01 \\
\hline 4 & 2.5 & 0.4 & 0.09 \\
\hline Reference & 4.1 & 0.3 & 0 \\
\hline
\end{tabular}

biomass estimates, the potential release of $\mathrm{N}$ was over $50 \mathrm{~kg}$ (about $150 \mathrm{~kg} \mathrm{ha}^{-1}$ ) and that of $\mathrm{P}$ more than $4 \mathrm{~kg}$ (ca. $13 \mathrm{~kg} \mathrm{ha}^{-1}$ ) when all dead biomass had decomposed.

\section{Ground and bottom layer biomass and its total nitrogen content in the spruce swamp}

Our limited data on $\mathrm{N}_{\text {тот }}$ content in live plant biomass allowed only for a comparison between the above-ground parts of vascular plants and mosses, and peat. The total $\mathrm{N}$ content of aboveground vegetation and peat dry mass ranged from $16.0 \mathrm{~g} \mathrm{~kg}^{-1}$ on transect 4 to $22.6 \mathrm{~g} \mathrm{~kg}^{-1}$ at the wet end of the buffer (Table 3 ). The $\mathrm{N}_{\text {тот }}$ content of peat varied from 9.2 to $21 \mathrm{~g} \mathrm{~kg}^{-1}$, the lowest value being obtained on the wet part of the buffer and the highest on the reference. Within the buffer, the peat layer was weakly decomposed

Table 3. $\mathrm{N}_{\text {тот }}$ contents in vegetation and peat dry mass $\left(\mathrm{g} \mathrm{kg}^{-1}\right)$, in living biomass (no peat), in peat, in vascular plants and in mosses of the spruce swamp.

\begin{tabular}{lccccc}
\hline Transect & \multicolumn{5}{c}{$\mathrm{N}_{\text {TOT }}$ contents $\left(\mathrm{g} \mathrm{kg}^{-1}\right.$ dry mass $)$} \\
\cline { 2 - 6 } & Total & $\begin{array}{c}\text { Living } \\
\text { biomass }\end{array}$ & Peat & $\begin{array}{c}\text { Vascular } \\
\text { plants }\end{array}$ & Mosses \\
\hline 1 & 22.6 & 20.8 & 9.2 & 23.0 & 18.0 \\
2 & 20.3 & 21.4 & 15.0 & 22.5 & 17.0 \\
3 & 22.0 & 24.5 & 12.0 & 26.3 & 19.0 \\
4 & 16.0 & & & & \\
Reference & 20.2 & 20.1 & 21.0 & 22.4 & 16.3 \\
\hline
\end{tabular}


and dominated by Sphagnum residues, while on the reference the peat was more decomposed, containing abundant wood remains. The dry mass per area of the moss layer on the reference, consisting mainly of forest mosses, was somewhat lower than that of the more Sphagnum dominated buffer (Table 3).

The above-ground dry biomass varied from $129 \mathrm{~g} \mathrm{~m}^{-2}$ to $177 \mathrm{~g} \mathrm{~m}^{-2}$ (Table 4). About $80 \%$ of the plot in transect 1 was subject to a strong overland inflow, which may have affected the vegetation coverage. However, the total moss biomass, including green parts of mosses or capitula of Sphagna, was generally lowest in the reference. The moss biomass increased towards the dry areas of the buffer, while the biomass of vascular plants decreased: e.g. Calamagrostis purpurea was more abundant and lush in the wet areas of the buffer. In the reference, herbs were more common than on the buffer. Overland flow had evidently led to the replacement of perennial dwarf shrubs by annual grasses and herbs.

\section{Water levels and water quality}

In the spruce swamp, the water table differed between seasons $(p \leq 0.0005)$, being higher during the spring flood and summer $(-13 \mathrm{~cm}$ from the soil surface) than in winter during the non-frost season $(-23 \mathrm{~cm})$, but no statistical significance emerged between the transects (Table 5). However, the small systematic differences were apparently critical for the non-flood tolerant vegetation. The water table level in the reference was actually lower and the aerobic

Table 4. Vegetation biomass, the biomass of mosses capitula and vascular plants and ferns of the spruce swamp. The overland water flow covered about $80 \%$ of the vegetation plot on transect 1 .

\begin{tabular}{lccc}
\hline Transect & $\begin{array}{c}\text { Vegetation } \\
\text { biomass } \\
\left(\mathrm{g} \mathrm{m}^{-2}\right)\end{array}$ & $\begin{array}{c}\text { Biomass of } \\
\text { mosses } \\
\left(\mathrm{g} \mathrm{m}^{-2}\right)\end{array}$ & $\begin{array}{c}\text { Biomass of } \\
\text { vascular plants } \\
\left(\mathrm{g} \mathrm{m}^{-2}\right)\end{array}$ \\
\hline 1 & 129 & 22 & 107 \\
2 & 167 & 80 & 87 \\
3 & 177 & 105 & 72 \\
4 & 159 & 132 & 27 \\
Reference & 151 & 26 & 125 \\
\hline
\end{tabular}

peat layer thicker than shown in Table 5, but it could not be documented as the water wells did not extend deep enough to capture the lowest water tables in summer. All the other transects can thus be compared with each other, but not with the reference.

The values of $\mathrm{pH}$ differed between transects $(p=0.001)$ and seasons (0.014) on the spruce swamp. The wet areas of the buffer differed from the reference, and transect 3 differed from transect 4 (Table 5). Also, transects 1 and 2 differed indicatively from transect 4 ( $p=0.062$ and $p=0.063$, respectively).

In the brook margin meadow, the water table showed differences between the transects ( $p$ $=0.036)$, but the linear mixed model could not resolve the full patterns of difference. Only transect $1(-8 \mathrm{~cm}, \mathrm{SE}=1.5)$ differed indicatively from transect $2(-20 \mathrm{~cm}, \mathrm{SE}=1.8, p=0.080)$. The water tables on transect 3 and the reference were -8 and $-17 \mathrm{~cm}(\mathrm{SE}=0.95$ and 1.77 , respectively). $\mathrm{pH}$ values did not differ significantly. In the buffer area, $\mathrm{pH}$ was $6.12 \pm 0.03$ and in the reference $6.06 \pm 0.10$.

During the sampling period, the concentration of $\mathrm{P}_{\text {тот }}$ in the spruce swamp buffer inflow decreased (Fig. 7), while in the brook margin meadow, the concentrations of $\mathrm{P}_{\text {тот }}$ and $\mathrm{PO}_{4}^{3-}$ increased. In both buffers, the concentrations of $\mathrm{N}_{\text {тот }}, \mathrm{NO}_{2}+\mathrm{NO}_{3}, \mathrm{P}_{\text {тот }}$ and $\mathrm{PO}_{4}^{3-}$ were occasionally higher in the outflow than in the inflow. Due to the diffuse water flow within and outside the buffer, we were not able to measure the nutrient balance in the buffer. Assuming a low ratio of precipitation and evapotranspiration within the relatively small buffer area, most of the water flows through the buffer. Nearly similar inflow and outflow concentrations of $\mathrm{N}$ and $\mathrm{P}$ in those conditions would indicate low net binding of the nutrients.

Table 5. Average water table depth \pm SE) and pH (minimum and maximum) in the spruce swamp.

\begin{tabular}{lccc}
\hline Transect & Water table $(\mathrm{cm}) \pm \mathrm{SE}$ & $\mathrm{pH}$ & Min-Max \\
\hline 1 & $-9 \pm 1.2$ & 5.15 & $4.52-5.99$ \\
2 & $-10 \pm 1.5$ & 5.12 & $4.58-6.53$ \\
3 & $-19 \pm 2.2$ & 4.92 & $4.33-6.39$ \\
4 & $-28 \pm 1.9$ & 5.70 & $4.74-6.60$ \\
Reference & $-32 \pm 2.2$ & 5.83 & $4.54-6.56$
\end{tabular}


Fig. 7. Concentrations of $\mathrm{N}_{\text {Tот }}, \mathrm{NO}_{3}+\mathrm{NO}_{2}, \mathrm{NH}_{4}^{+}$ ( $A$ and $D), P_{\text {TOT }}(B$ and $E$ ) and $\mathrm{PO}_{4}{ }^{3-}(\mathrm{C}$ and $\mathrm{F})$ in the water inlet and outlet in the spruce swamp and the brook margin meadow.

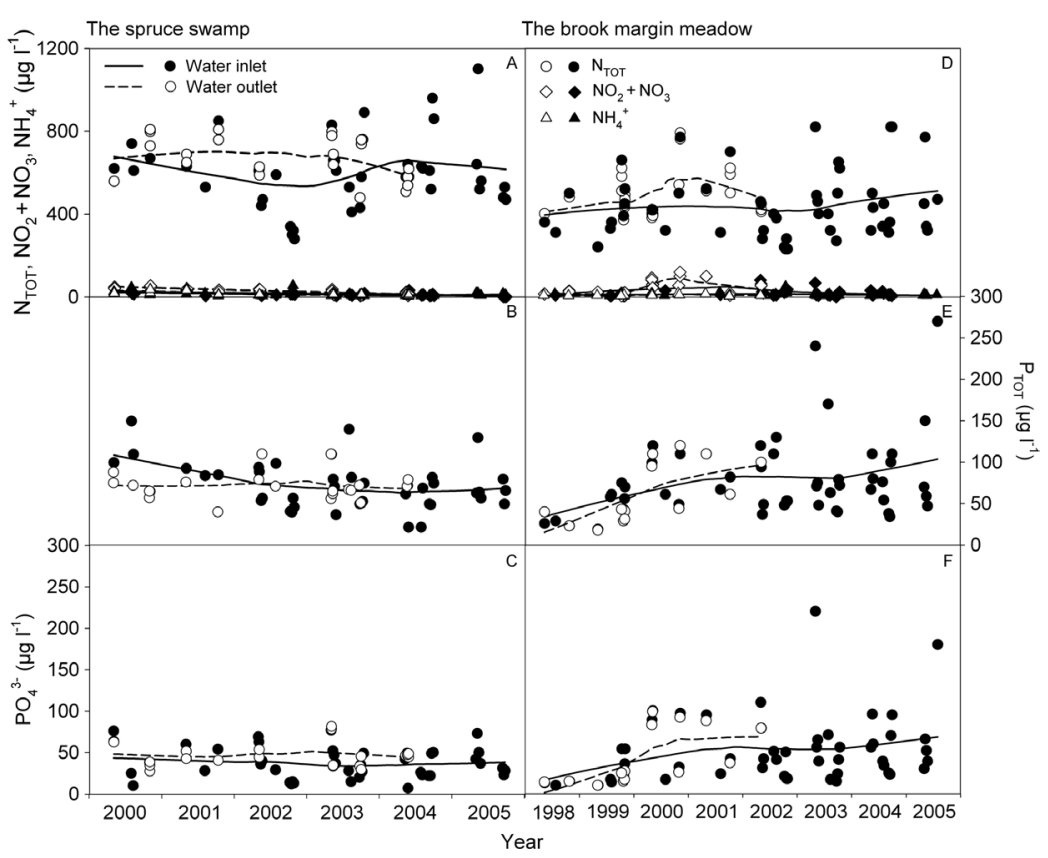

some species already occupying the sites. In the spruce swamp, the species indicating flooding according to mire biotope descriptions (Eurola et al. 1995), e.g. Calamagrostis purpurea, Sphagnum riparium, $S$. girgensohnii, increased, while the forest mosses and shrubs (e.g. Vaccinium myrtillus, Pleurozium schreberi and Hylocomium splendens) decreased in coverage. The decline of original spruce swamp species especially seems a more prominent sign of flooding than colonization of the buffer by new, flood-tolerant species. Some species, such as Viola palustris and Trientalis europaea, kept their positions in the communities of the buffer. Needle loss after the death of trees and the gaps formed by fallen trunks increased light penetration to the ground vegetation. Together with a lowered $\mathrm{pH}$ due to the spread of acidic Sphagnum species in the buffer, the improved irradiation conditions may have favored $C$. purpurea and impaired the growth of ferns and forest species. The change in vegetation is probably still ongoing, since the greatest exchange of forest species for aquatictolerant species has taken place predominantly at the uppermost end of the buffer.

On the brook margin meadow, the buffer vegetation type represented at least temporarily flooding herb-grass spruce mire, while the referRather than the disappearance or appearance
of species, we found a decline or expansion of 
ence sub-site was swamp fen (Figs. 5 and 6). The natural flooding effect was indicated by Calla palustris, Lysimachia thyrsiflora and Sphagnum riparium on the herb-grass spruce mire type especially, on plots close to the brook; the presence of these species was decreasing towards the sedimentation pond. Annual thawing could release nutrients from soil, which may also affect the vegetation of the buffer. Calamagrostis purpurea and Carex canescens may have increased after buffer construction, as they were the most abundant species just below the sedimentation pond. Some species known to indicate flooding conditions in mires (Potentilla palustris, Calliergon cordifolium and Sphagnum riparium) were common in the entire buffer area. Similarly to our observations, Huttunen et al. (1996) found no great differences in the flora between the overland flow area and a sedge-dominated mesotrophic fen reference, although some species were favored on the flooded sites. It was not possible to show in our brook margin meadow, which changes were caused by buffer construction and which by spring flooding of the brook. It is notable that buffers should not be constructed at sites affected by frequent natural floods (e.g. Joensuu et al. 2004).

The decrease in forest species and the increase in flooding-tolerant species may have affected the vegetation biomass (Table 4) on the spruce swamp buffer. The total above ground vegetation biomass was quite similar on all five plots in the spruce swamp (Table 4), but overland water flows seemed to increase the moss biomass. Also, the combined vascular plant biomass was higher in the wet areas of the buffer as compared with that in the dry ones, but still lower than in the fern spruce mire type reference. This suggests that the vegetation change is still continuing. Liikanen et al. (2006) measured an almost two-fold growth in plant biomass after a ten-year monitoring period in a wetland receiving runoff from a peat mining site, the below-ground biomass also being significantly higher in the buffer (Huttunen et al. 1996). Silvan et al. (2004) reported a significant increase in plant biomass after experimental nutrient addition in a peatland forestry buffer, observing the greatest increase in Eriophorum vaginatum and Sphagnum, although the proportional increase in above-ground herb biomass was highest. No species that are abundant on our spruce swamp site are known to have a large below-ground biomass. Thus it does not seem possible that large quantities of nutrients could be bound in below-ground biomass there. Only peat-forming Sphagnum species could have the potential to trap nutrients from the active nutrient cycle.

In the spruce swamp, the $\mathrm{N}$ content in the total above-ground vegetation and surface peat layer appeared to be similar in the buffer and in the reference, with reservations due to our limited data set (Table 3). Although we measured lower peat $\mathrm{N}$ concentrations in the buffer than in the reference, live vegetation $\mathrm{N}$ content varied inversely. In a constructed wetland receiving peat mining runoff waters, the increase in total $\mathrm{N}$ content may be as high as $40 \%$ (Huttunen et al. 1996). In a buffer prepared for peatland forestry an increase of $25 \%$ (Silvan et al. 2004) in the above-ground biomass was reported after a nutrient addition experiment. Since no such change was found in our buffer, and the nutrient inflow was low (Fig. 7), the retention of nutrients was probably also low.

Buffers may bind nutrients in the plant biomass by microbial immobilization and chemical absorption (Heikkinen et al. 1995). The retention capacity by plant and microbial uptake may initially be high, but the ecosystem becomes biologically and chemically saturated within only a few years (Heikkinen et al. 1995). With our meagre data on peat and plant biomass and $\mathrm{N}$ content, we were not able to show a significant increase or clear difference in the total $\mathrm{N}$ binding capacity at different distances from the water inlet as compared with the reference (Tables 3 and 4). Furthermore, we did not measure the $P$ content of the biomass, which could be more important than $\mathrm{N}$ binding as regards water protection measures. According to Silvan et al. (2004), P concentration in plant tissues did not increase after nutrient addition to the buffer, but the increased plant biomass after fertilization bound more P. On the other hand, Huttunen et al. (1996) reported a 5\% decrease in total P storage in the buffer plants as compared with that in the reference area, in spite of an increase in total phytomass. Väänänen et al. (2006) also reported 
negligible $\mathrm{P}$ retention in mosses and vascular plants after fertilizer addition. Laiho et al. (2006) showed in a chronosequence study, that drainage increased the net $\mathrm{P}$ uptake of the vascular plant compartment. The flooding or rewetting of a peatland ecosystem that takes place in buffer establishment may produce a contrary effect.

A significant reason for nutrient release in a buffer such as the spruce swamp may be the dying and decomposing tree stand. Needles release nutrients rapidly after the death of the tree, while stem wood holds the nutrients longer (see Palviainen et al. 2004). At least some of these nutrients may leach, while some may be bound. Furthermore, as nutrient consumption is reduced by tree death, more nutrients become available. If trees were harvested in association with buffer construction, pressure for nutrient leaching could be reduced accordingly.

A practical problem is the formation of bypass water channels in the tracks of forest machinery. The channels may reduce the contact time of inflow water with the soil. The $\mathrm{N}$ and $\mathrm{P}$ concentrations in the water inflow and outflow of the spruce swamp buffer and in the brook margin meadow were typical of surface or vadose waters in drained peatlands (see Joensuu et al. 2001a), suggesting that only little enrichment occurred before the buffer. Furthermore, nutrients cannot accumulate if the buffer is constructed in an area vulnerable to spring floods, which may flush the nutrients already adsorbed by the buffer.

\section{Conclusions}

On the basis of what is empirically known on species indication of flooding and nutrient status in peatland biotope classifications, raising of the water table rather than increased nutrient load seems to be the factor causing vegetation changes in peatland buffers. A decrease in canopy coverage as a result of degeneration of the conifer stand is important in creating gaps and reducing canopy light extinction. The vegetation change in favor of flood-tolerant species can be used as a tool indicative of the effective area of water flows in the original area reserved as a peatland buffer.

\section{Acknowledgements}

Our thanks are due to research technician Markku Tiainen and the research assistants of the Finnish Forest Research Institute, Nurmes Office, for the tree stand measurements. We also thank Dr. Eeva-Stiina Tuittila and Dr. Raija Laiho from University of Helsinki for their advice on sampling the vegetation for the biomass and $\mathrm{N}_{\text {Tот }}$ analysis, Seppo $\mathrm{M}$. Heikkinen from Metsähallitus for information concerning the clear-cut and the North Karelia and Pirkanmaa Regional Environment Centres for nutrient analysis. We also thank research secretary Leena Karvinen for preparing the maps. Rosemary Mackenzie (M.A.) revised the English language of the article. The work was funded by the Maj and Tor Nessling Foundation.

\section{References}

Cajander, A. K. 1913: Studien über die Moore Finnlands. Acta Forestalia Fennica 2: 1-208.

Eurola, S., Huttunen, A. \& Kukko-Oja, K. 1995: Oulanka raportit. Suokasvillisuusopas. - Oulun yliopisto.

Finér, L. 1989: Biomass and nutrient cycle in fertilized and unfertilized pine, mixed birch and pine and spruce stands on a drained mire. - Acta Forestalia Fennica 208: 1-63.

Heikkinen, K., Ihme, R., Osma, A.-M. \& Hartikainen, H. 1995: Phosphate removal by peat from peat mining drainage water during overland flow wetland treatment. - Journal of Environmental Quality 24: 597-602.

Huttunen, A., Heikkinen, K. \& Ihme, R. 1996: Nutrient retention in the vegetation of an overland flow treatment system in northern Finland. - Aquatic Botany 55: 61-73.

Joensuu, S., Ahti, E. \& Vuollekoski, M. 2001a: Discharge water quality from old ditch networks in Finnish peatland forests. - Suo 52: 1-15.

Joensuu, S., Ahti, E. \& Vuollekoski, M. 2001b: Long-term effects of maintaining ditch networks on runoff water quality. - Suo 52: 17-28.

Joensuu, S., Makkonen, T. \& Matila, A. 2004: Metsätalouden vesiensuojelu. - Metsätalouden kehittämiskeskus Tapio, Helsinki.

Laiho, R., Penttilä, T., Vasander, H., Laine, J. \& Alm, J. 2006: Post-drainage dynamics of $\mathrm{P}$ uptake by trees and ground vegetation in Scots pine dominated peatlands. Suo 57: 1-10.

Laine, J. \& Vasander, H. 2008: Suotyypit ja niiden tunnistaminen. - Karisto Oy, Hämeenlinna.

Liikanen, A., Huttunen, J. T., Karjalainen, S. M., Heikkinen, K., Väisänen, T., Nykänen, H. \& Martikainen, P. J. 2006: Temporal and seasonal changes in greenhouse gas emissions from a constructed wetland purifying peat mining runoff waters. - Ecological Engineering 26: 241-251.

Liljaniemi, P., Vuori, K.-M., Tossavainen, T., Kotanen, J., Haapanen, M., Lepistö, A. \& Kenttämies, K. 2003: Effectiveness of constructed overland flow areas in 
decreasing diffuse pollution from forest drainages. Environmental Management 32: 602-613.

Mannerkoski, H., Finér, L., Piirainen, S. \& Starr, M. 2005: Effect of clear-cutting and site preparation on the level and quality of groundwater in some headwater catchments in eastern Finland. - Forest Ecology and Management 220: 107-117.

Morris, D. M. 2009: Changes in DOC and DON fluxes in response to harvest intensity of black-spruce-dominated forest ecosystems in northwestern Ontario. - Canadian Journal of Soil Science 89: 67-79.

Nieminen, M. 2004: Export of dissolved organic carbon, nitrogen and phosphorus following clear-cutting of three Norway spruce forests growing on drained peatlands in southern Finland. - Silva Fennica 38: 123-132.

Palviainen, M., Finér, L., Kurka, A.-M., Mannerkoski, H., Piirainen, S. \& Starr, M. 2004: Decomposition and nutrient release from logging residues after clear-cutting of mixed boreal forest. - Plant and Soil 263: 53-67.

Peltola, A. (ed.) 2008: Metsätilastollinen vuosikirja 2008. Metsäntutkimuslaitos, Vantaa.

Piirainen, S., Finér, L., Mannerkoski, H. \& Starr, M. 2007: Carbon, nitrogen and phosphorus leaching after site preparation at a boreal forest clear-cut area. - Forest Ecology and Management 243: 10-18.

Piirainen, S., Finér, L., Mannerkoski, H. \& Starr, M. 2004: Effects of forest clear-cutting on the sulphur, phosphorus and base cation fluxes through podsolic soil horizons. Biogeochemistry 69: 405-424.

Repola, J., Ojansuu, R. \& Kukkola, M. 2007: Biomass func- tions for Scots pine, Norway spruce and birch in Finland. - Working Papers of the Finnish Forest Research Institute 53: 1-28.

Saura, M., Sallantaus, T., Bilaletdin, Ä. \& Frisk, T. 1995: Metsänlannoitteiden huuhtoutuminen Kalliojärven valuma-alueelta. - In: Saukkonen, S. \& Kenttämies, K. (eds.), Metsätalouden vesistövaikutukset ja niiden torjunta. METVE-projektin loppuraportti: 87-104. Suomen ympäristökeskus, Helsinki.

Silvan, N., Vasander, H., Karsisto, M. \& Laine, J. 2003: Microbial immobilization of added nitrogen and phosphorus in constructed wetland buffer. - Applied Soil Ecology 24: 143-149.

Silvan, N., Vasander, H. \& Laine, J. 2004: Vegetation is the main factor in nutrient retention in a constructed wetland buffer. - Plant and Soil 258: 179-187.

Sollins, P. \& McCorison, F. M. 1981: Nitrogen and carbon solution chemistry of an old growth coniferous forest watershed before and after cutting. - Water Resources Research 17: 1409-1418.

Väänänen, R., Nieminen, M., Vuollekoski, M. \& Ilvesniemi, H. 2006: Retention of phosphorus in soil and vegetation of a buffer zone area during snowmelt peak flow in southern Finland. - Water, Air and Soil Pollution 177: 103-118.

Väänänen, R., Nieminen, M., Vuollekoski, M., Nousiainen, H, Sallantaus, T., Tuittila, E.-S. \& Ilvesniemi, H. 2008: Retention of phosphorus in peatland buffer zones at six forested catchments in southern Finland. - Silva Fennica 42: 211-231.

Appendix 1. List of species on the spruce swamp.

Ground layer: Agrostis canina, Betula pubescens, Calamagrostis purpurea, Carex canescens, Carex globularis, Deschampsia cespitosa, Dryopteris carthusiana, Dryopteris expansa, Gymnocarpium dryopteris, Epilobium angustifolium, Epilobium palustre, Equisetum sylvaticum, Juncus filiformis, Linnaea borealis, Luzula pilosa, Maianthemum bifolium, Orthilia secunda, Oxalis acetosella, Picea abies, Rubus chamaemorus, Trientalis europaea, Vaccinium myrtillus, Vaccinium vitis-idaea, Viola palustris

Bottom layer: Aulacomnium palustre, Brachythecium sp., Calliergon cordifolium, Straminergon stramineum, Dicranum majus, Dicranum polysetum, Hepaticae, Hylocomium splendens, Pellia sp., Plagiomnium ellipticum, Plagiothecium sp., Pleurozium schreberi, Pohlia nutans, Polytrichum commune, Ptilium crista-castrensis, Sphagnum angustifolium, Sphagnum centrale, Sphagnum girgensohnii, Sphagnum riparium, Sphagnum russowii, Sphagnum squarrosum, Tetraphis pellucida, Warnstorfia exannulata

Appendix 2. List of species on the brook margin meadow.

Ground layer: Betula nana, Betula pubescens, Calamagrostis canescens, Calamagrostis purpurea, Calla palustris, Carex canescens, Carex globularis, Carex juncella, Carex lasiocarpa, Chamaedaphne calyculata, Cicuta virosa, Epilobium angustifolium, Epilobium palustre, Equisetum sylvaticum, Galium palustre, Ledum palustre, Peucedanum palustre, Lysimachia thyrsiflora, Menyanthes trifoliata, Pinus sylvestris, Potentilla palustris, Rubus arcticus, Rubus chamaemorus, Trientalis europaea, Vaccinium oxycoccos, Vaccinium uliginosum, Vaccinium vitis-idaea, Viola palustris

Bottom layer: Aulacomnium palustre, Brachythecium sp., Calliergon cordifolium, Dicranum scoparium, Hepaticae, Marchantia, Plagiothecium sp., Pleurozium schreberi, Pohlia nutans, Polytrichum commune, Polytrichum strictum, Sphagnum fallax, Sphagnum fimbriatum, Sphagnum girgensohnii, Sphagnum riparium, Sphagnum squarrosum, Tetraphis pellucida 